\title{
PERSEPSI PEMUDA TENTANG KEISTIMEWAAN YOGYAKARTA BAGI KETAHANAN POLITIK WILAYAH (Studi Pada Pengurus Karang Taruna Kabupaten Bantul Periode 2014-2019)
}

\author{
Muhammad Pranasik Faihaan \\ Karang Taruna DIY \\ asyik_uekk@yahoo.com
}

\begin{abstract}
The goals in this research were to knew the youth perceptions about the privilege of Yogyakarta for regional political resilience of Yogyakarta Special Region. The purpose of this study was to answered the research questions: regarding the condition Karang Taruna Bantul at district level and how the youth perceptions about the privilege of Yogyakarta Special Region of Yogyakarta political resilience. This research was a field (field study research) using descriptive research method. The researcher did the collection of data using observation, in-depth interviews, and collection of documentation associated with the subject and object of research.

The youth people as a board of Karang Taruna Bantul supported, agreed and ready to carried out the determination of the Sultan and Pakualam as governor. The impact of the youth's perception of the status of Yogyakarta privilege could be seen with the program which many did several activities related to the privilege of Yogyakarta. Other support that was done by inserting a distinctive agenda in programs such as coming to socialized the laws and regulations derivative of privilege to the general public. The deferences of the youth perceptions was look at the opinion about Sultan Hamengku Buwono X succession. Allthough, There were diferent perceptions about The perceptions, The Regional political resilience in Yogyakarta Special Region remained relatively resilient to the legitimacy of the people of Yogyakarta and the central government.
\end{abstract}

Keywords: Perception, Youth, Yogyakarta Privileges, Regional Political Resilience

\begin{abstract}
ABSTRAK
Tujuan dalam penelitian ini adalah untuk mengetahui persepsi pemuda tentang keistimewaan Yogyakarta dan implikasinya bagi ketahanan politik Daerah Istimewaan Yogyakarta. Penelitian ini merupakan penelitian lapangan (field study research) dengan menggunakan metode penelitian diskriptif (descriptive research). Pengumpulan data menggunakan teknik observasi, wawancara mendalam, dan pengumpulan berbagai dokumentasi yang terkait dengan subjek maupun objek penelitian.

Dampak dari persepsi pemuda terhadap status keistimewaan Yogyakarta bisa dilihat dengan program kerja Karang Taruna Kabupaten Bantul yang banyak melakukan berbagai kegiatan yang berkaitan dengan agenda keistimewan Yogyakarta. Pemuda yang duduk sebagai pengurus Karang Taruna Kabupaten Bantul mendukung, setuju dan siap melaksanakan penetapan Sri Sultan dan Pakualam sebagai gubernur. Dukungan lain yakni dilakukan dengan memasukkan agenda keistimewaan dalam program-program Karang Taruna Kabupaten Bantul seperti ikut mensosialisasikan UU serta peraturan turunan tentang keistimewaan kepada masyarakat luas. Perbedaan persepsi pemuda terihat jelas pada pandangan tentang suksesi kepemimpinan pasca Sri Sultan Hamengku Buwono X.
\end{abstract}


Meskipun terjadi perbedaan persepsi tentang ketahanan politik wilayah di Daerah Istimewa Yogyakarta tetap relatif tangguh dengan adanya legitimasi dari rakyat Yogyakarta dan pemerintah pusat.

Kata Kunci : Persepsi, Pemuda, Keistimewaan Yogyakarta, Ketahanan Politik Wilayah

\section{PENGANTAR}

Daerah Istimewa Yogyakarta (DIY) merupakan daerah yang memiliki status keistimewaan berdasarkan Historis, Yuridis, dan sosiologis. Ditinjau dari segi historis, sebelum Proklamasi Kemerdekaan Indonesia, Kesultanan Yogyakarta sudah memiliki status sebagai kerajaan/negara bagian (Dependet State) dalam pemerintahan penjajah mulai dari VOC, Hindia Perancis, Hindia Belanda, dan terakhir Tentara Angkatan Darat XVI Jepang. Status ini membawa konsekuensi hukum dan politik berupa kewenangan untuk mengatur dan mengurus wilayah (negaranya) sendiri di bawah pengawasan pemerintah penjajah (Bahar, 1933). Pasca runtuhnya kekuasaan Jepang di Indonesia, sebenarnya Yogyakarta memiliki kesempatan untuk menjadi negara sendiri. Akan tetapi, kedua pemimpin Yogyakarta, Sultan HB IX dan Paku Alam VIII, justru memilih bergabung dalam Negara Kesatuan Republik Indonesia. Sejak saat itu, Yogyakarta ditetapkan sebagai Provinsi Istimewa Yogyakarta berdasarkan UndangUndang Nomor 3 Tahun 1950 sebagaimana telah diubah dengan Undang-Undang Nomor 19 Tahun 1950 dan berlaku pada tanggal 15 Agustus 1950.

Meskipun status keistimewaan Yogyakarta sudah ditetapkan sejak 1950, namun dalam perjalannya tidak semulus yang dibayangkan. Beberapa waktu lalu, kesitimewaan Yogyakarta sempat menjadi bola panas yang menyebabkan terjadinya perseteruan antara elit pemerintah pusat dengan pemerintah daerah, bahkan sampai ke akar rumput.
Survey yang dilakukan Kompas pada 13 April 2010, menunjukkan sebanyak 74.9\% masyarakat Yogayakarta setuju jabatan Gubernur dari keluarga keraton. Hasil survey tahun 2010 Universitas Muhammadiyah Yogyakarta menunjukkan bahwa 93.2\% rakyat Yogyakarta pro penetapan Sri Sultan Hamengkubuwono dan Sri Paku Alam sebagai Gubernur dan Wakil Gubernur DIY.

Pada tanggal 25 Maret 2008, sekitar 10.000 orang dari berbagai Kabupaten di DIY menggelar sidang rakyat di halaman gedung DPRD DIY yang mendesak DPRD membuat keputusan politik sesuai aspirasi masyarakat DIY dan menentang RUUK yang bertentangan dengan aspirasi masyarakat. Berbagai elemen masyarakat seperti Paguyuban Gentaraja, Ismaya (paguyuban lurah), Paguyuban Dukuh se-DIY, Paguyuban budayawan, Karang Taruna di Yogyakarta, forum Masyarakat Yogyakarta di Jakarta dan sekitarnya menghendaki penetapan dalam pengisian Gubernur dan Wakil Gubernur DIY. Lembaga negara DPDDIY, DPRD DIY, DPRD Kabupaten Sleman, DPRD Kabupaten Bantul, DPRD Kabupaten Gunung Kidul, DPRD Kabupaten Kulon Progo, DPRD Kota Yogyakarta, Pemerintah Provinsi DIY, Pemerintah Kabupaten SeDIY, Keluarga Keraton Ngayogyakarta Hadiningrat, keluarga Kadipaten Paku Alaman menghendaki penetapan dalam pengisian Gubernur dan Wakil Gubernur DIY.

Gejolak politik tersebut tentunya membuat ketahanan wilayah Yogyakarta terguncang. Jika dilihat dari prinsip-prinsip ketahanan nasional, maka ketahanan wilayah 
atau ketahanan daerah mencakup seluruh aspek kehidupan yang dituntut untuk bisa menghadapi dan mengatasi segala hambatan dan tantangan yang ada, baik keadaan alam, letak geografi, demografi, maupun keadaan ekonomi, sosial, politik dan budaya.

Mengacu pada prinsip-prinsip ketahanan nasional tersebut, maka untuk menjaga ketahanan wilayah, peran seluruh sumber daya yang ada sangat dibutuhkan. Dalam hal ini sumber daya manusia (SDM) memiliki peran yang sangat penting, terutama generasi mudah yang ada di wilayah Yogyakarta.

Pemuda merupakan tulang punggung negara, karenanya masa depan suatu negara sangat tergantung dari peran pemuda itu sendiri. Dilihat dari segi sejarahnya, perkembangan bangsa ini tidak terlepas dari peran serta kaum muda. Mulai dari Sumpah Pemuda 1928, gerakan mahasiswa pro-demokrasi yang menuntut perubahan sejak 1961, 1978 dan 1998, adalah bukti adanya interrelasi politik kaum muda dengan dinamika politik Indonesia.

Dalam konteks kekinian, pemuda diharapkan mampu berperan aktif dalam mengatasi persoalan bangsa. Melihat berbagai persoalan yang dihadapai bangsa Indonesia saat ini. Pemuda dapat dijadikan sebagai driving force pembangunan daerah untuk mendukung terwujudnya ketahanan politik wilayah. Atas dasar itulah penelitian ini mengamabil judul "Persepsi Pemuda tentang Keistimewaan Yogyakarta Dan Implikasinya Bagi Ketahanan Politik Wilayah” (Studi Pada Pengurus Karang Taruna Kabupaten Bantul 2014 - 2018)”.

Penelitian ini merupakan penelitian lapangan (field study research) dengan menggunakan metode penelitian diskriptif (descriptive researc). Penelitian deskripti dimaksudkan untuk memberi sebuah gambaran mengenai suatu individu, keadaan, gejala atau kelompok tertentu. Sedangkan pendekatan yang digunakan dalam penelitian ini adalah pendekatakan kualitatif, yang bermaksud untuk memahami fenomena tentang apa yang dialami oleh subyek penelitian, misalnya perilaku, persepsi, pandangan, motivasi atau tindakan sehari-hari.

Subyek penelitian ini adalah aktivis pemuda yang tergabung dalam kepengurusan Karang Taruna Kabupaten Bantul masa jabatan priode 2014-2018. Obyek penelitian ini adalah persepsi pemuda terhadap status keistimewaan Daerah Istimewa Yogyakarta dan implikasinya bagi ketahanan politik wilayah.

Sumber data dari penelitian ini adalah hasil wawancara dari aktivis pemuda Kabupaten Bantul dan juga dokumentasi baik berupa dokumen tertulis dan lainnya yang berhubungan dengan obyek dan subjek penelitian.

Untuk memperoleh data primer yang dibutuhkan dalam penelitian ini, maka peneliti menggunakan beberapa teknik penelitian.

Pertama, dokumentasi. Dokumentasi merupakan teknik mencari data yang berupa catatan, transkip, buku, surat kabar, majalah, prasasti, notulen rapat, lengger, agenda dan sebagainya (Arikunto, 2002). Dokumentasi yang dimaksud dalam penelitian ini adalah arsip maupun literatur yang berhubungan dengan obyek dan subjek penelitian.

Kedua, wawancara. Wawancara ialah teknik pengumpulan data yang dilakukan dengan cara tanya jawab secara lisan dan bertatap muka secara langsung dan dengan arah serta tujuan yang telah ditetapkan. Untuk memperoleh data terkait dengan persepsi 
pemuda tentang keistimewaan Yogyakarta dan implikasinya terhadap ketahanan politik wilayah di Daerah Istimewa Yogyakarta, maka wawancara dilakukan secara mendalam dan terstruktur.

Ketiga, Focus Group Discussion (FGD) yaitu, diskusi terfokus dari suatu group untuk membahas suatu masalah tertentu, dalam suasana informal dan santai. Teknik ini digunakan untuk mengungkap pemaknaan dari suatu kelompok terhadap permasalahan tertentu yang dalam hal ini permasalahannya ialah Persepsi Pemuda Tentang Keistimewaan Yogyakarta Dan Implikasinya Bagi Ketahanan Politik Wilayah. Pada metode ini peneliti bertindak sebagai moderator.

Untuk memperoleh data yang valid maka peneliti melakukan analisis data. Dalam hal ini proses analisis data dilakukan pada waktu bersamaan dengan proses pengumpulan data berlangsung secara terus menerus. Teknik analisis data yang digunakan dalam penelitian ini adalah:

Pertama, peneliti mengumpulkan berbagai literatur, baik yang berupa buku, jurnal, tesis, disertasi, dan data-data dari internet yang berkaitan dengan obyek yang ingin dikaji dalam penelitian ini. Data-data yang telah terkumpul kemudian disusun sebagai latar belakang masalah yang akan menjadi topik atau pokok bahasan dalam penelitian ini.

Kedua, setelah data-data terkumpul, maka peneliti melakukan tahap reduksi data. Reduksi data merupakan bentuk analisis yang mempertegas, memperpendek, membuat fokus, membuang hal yang tidak penting dan mengatur sedemikian rupa sehingga kesimpulan akhir dapat dilakukan. Pada tahap ini dilakukan proses penyeleksian, pemfokusan, penyederhanaan pengabstraksian data dari field note dan transkrip hasil wawancara. Proses ini berlangsung sepanjang penelitian dilakukan dengan membuat singkatan, kategorisasi, memusatkan tema, menentukan batas-batas permasalahan.

Ketiga, Display data atau penyajian data. Yang dimaksud display data ialah sekumpulan informasi tersusun yang memberi kemungkinan adanya penarikan kesimpulan dan pengambilan tindakan. Tujuannya adalah untuk mempermudah peneliti dalam memahami apa yang sedang terjadi dan apa yang harus dilakukan selanjutnya.

Keempat, verifikasi data. Dalam hal ini dari awal pengumpulan data, peneliti sudah harus memahami apa arti dari berbagai hal yang ditemui dengan mulai melakukan pencatatan pola-pola, pernyataan-pernyataan, konfigurasi-konfigurasi, alur sebab-akibat dan berbagai proposisi. Hal itu diverifikasi dengan temuan-temuan data selanjutnya dan akhirnya sampai pada penarikan kesimpulan akhir.

\section{PEMBAHASAN}

Menurut Desiderato, dalam buku Investigating Behavior Principles of Psychology, seperti dikutip oleh Jalaludin Rakhmat, menyatakan pengertian persepsi adalah pengalaman tentang objek, peristiwa atau hubungan yang diperoleh dalam menyimpulkan informasi dan menafsirkan pesan. Persepsi ialah memberikan makna pada stimuli indrawi. Persepsi timbul karena adanya respon terhadap stimulus. Stimulus yang diterima seseorang sangat komplek. Stimulus masuk ke dalam otak, kemudian diartikan, ditafsirkan serta diberi makna melalui proses yang rumit baru kemudian dihasilkan persepsi (Rakhmat, 2005). 
Muhammad Pranasik Faihaan -- Persepsi Pemuda Tentang Keistimewaan Yogyakarta Bagi Ketahanan Politik Wilayah (Studi Pada Pengurus Karang Taruna Kabupaten Bantul Periode 2014-2019)

Sedangkan pemuda, Pemuda dalam kosakata Bahasa Indonesia memiliki terminologi yang beragam. Pemuda umumnya ditempatkan sebagai subjek pemberdayaan yang memiliki kualifikasi efektif dengan kemampuan dan keterampilan yang bisa digunakan untuk menyelesaikan permasalahan yang dihadapi bangsa.

Word Health Organization (WHO) mendefinisikan pemuda sebagai seseorang yang berusia antara 10 tahun sampai dengan 24 tahun. Kanada menyebutkan batasan paling tinggi 24 tahun dengan kategori remaja 13 tahun sampai 19 tahun dan muda antara 20 tahun sampai 24 tahun sesuai dengan perkembangan sosial, psikologi, dan kesehatan.

Konsep pemuda sesungguhnya memiliki makna yang kompleks, sehingga tidak jarang orang selalu mempermasalahkan definisi baku dari arti pemuda. Para pakar menyebutkan bahwa pemuda atau generasi muda adalah konsep yang sering dibentuk oleh nilai-nilai, maksudnya bukan istilah ilmiah, tapi lebih sering merupakan pengertian idiologis.

Keistimewaan Yogyakarta, merupakan status yang diberikan pada Daerah Istimewa Yogyakarta dan tercantum dalam UndangUndang Nomor 13 Tahun 2012. Ada beberapa dasar yang melatarbelakangi status keistimewaan diberikan kepada Yogyakarta, yaitu:

Pertama, konsepsi filosofis, dalam hal ini kesitimewaan Yogyakarta bukan hanya dilandasari oleh filosofi masyarakat, tetapi juga menjadi bagian konsisten dengan filosofi pendirian Negara Indonesia (Atmakusuma, 1982). Tidak hanya itu, masyarakat Yogyakarta memiliki nilai-nilai tradisi luhur masa lalu yang kental dan kuat mengakar pada tingkat bawah (grassroot).
Kedua, konsepsi yuridis. Konsepsi ini jelas tertuang dalam Undang-Undang Keistimewaan Yogyakarta, khususnya undang-undang yang terbaru yakni UU No 13 Tahun 2012. Dalam undang-undang tersebut dijelaskan, pada pasal 1 ayat 1 bahwa DIY adalah daerah provinsi yang mempunyai keistimewaan dalam menyelenggarakan urusan pemerintahan dalam rangka Negara Kesatuan Republik Indonesia. Pada pasal yang sama ayat 2 dijelaskan, bahwa keistimewaan adalah keistimewaan kedudukan hukum yang dimiliki oleh DIY berdasarkan sejarah dan hak asalusul Undang-Undang Dasar Negara Republik Indonesia Tahun 1945 untuk mengatur dan mengurusi kewenangan istimewa. Pada pasal 1 ayat 3 dijelaskan bahwa kewenangan istimewa ialah wewenang tambahan tertentu yang dimiliki DIY selain wewenang sebagaimana ditentukan dalam undang-undang tentang pemerintahan daerah.

Ketiga, secara geneologis, predikat keistimewaan Yogyakarta dapat ditinjau dari amanat Sri Paduka Ingkang Sinuwun Kandjeng Sultan Hamengku Buwono IX dan amanat Sri Paduka Kanjeng Gusti Pangeran Adipati Ario Paku Alam VII. Kedua amanat tersebut bisa disebut sebagai novum hukum yang menyatakan status keistimewaan Yogyakarta dalam ranah yuridis formal.

Ketahanan nasional berarti suatu kondisi ideal yang harus diwujudkan oleh Republik Indonesia. Kondisi ideal yang dimaksudkan dalam konsepsi ketahanan nasional dapat diterjemahkan ke dalam konsep “astagatra.” Astagatra itu sendiri merupakan metode untuk mengukur kondisi suatu wilayah dilihat dari sudut pandang gatra geografi, gatra kekayaan alam, gatra kependudukan, gatra ideologi, gatra politik, gatra ekonomi, gatra sosial 
budaya, dan gatra pertahanan keamanan (Lemhannas, 1997).

Ketahanan politik merupakan ketahanan yang berintikan kehidupan politik yang damai, tertib, adil, jujur dan demokratis. Ketahanan politik tersebut adalah usaha untuk menciptakan stabilitas politik dan untuk mengatasi segala ancaman, tantangan, hambatan dan gangguan, baik yang datang dariluar negeri maupun dari dalam negeri. Ancaman yang dimaksud adalah ancaman yang dapat membahayakan kelangsungan kehidupan bangsa dan negara Indonesia (Lemhannas, 1989).

Mengacu pada pendapat di atas, maka yang dimaksud dengan gatra politik adalah kondisi politik suatu wilayah yang diidealkan dalam konsep ketahanan nasional. Kondisi politik yang ideal dalam konsep ketahanan nasional salah satunya adalah demokratis, pemerintahan yang berdasarkan recht, pemerintahan tidak absolut (kekuasaan tidak tak terbatas), berdasarkan Pancasila dan UUD 45. Terlihat dalam uraian di atas bahwa suatu wilayah dapat dikatakan memiliki ketahanan politik jika kehidupan politiknya demokratis. Salah satu ukuran demokratis tidaknya suatu wilayah adalah pelaksanaan pemilu (Lemhannas, 1997).

\section{Karang Taruna Kabupaten Bantul}

Karang Taruna adalah suatu organisasi kepemudaan yang ada di Indonesia dan merupakan sebuah wadah tempat pengembangan jiwa sosial generasi muda, Karang Taruna tumbuh atas kesadaran dan rasa tanggung jawab sosial dari masyarakat dan untuk masyarakat itu sendiri khususnya generasi muda yang ada di suatu wilayah desa, kelurahan atau komunitas sosial yang sederajat, terutama bergerak pada bidangbidang kesejahteraan sosial. Seperti dalam bidang ekonomi, olahraga, keterampilan, keagamaan dan kesenian sesuai dengan tujuan didirikannya Karang Taruna, yaitu untuk memberikan pembinaan dan pemberdayaan kepada para remaja yang ada di dalam suatu desa atau wilayah itu sediri (Peraturan Menteri Sosial, 2010).

Karang Taruna Kabupaten Bantul merupakan organisasi kepemudaan sehingga otomatis anggotanya sebagian besar merupakan pemuda. Dalam aturan keanggotaan dan kepengurusan Karang Taruna tentang batasan umur pengurusnya berbeda dengan UU Kepemudaan. UU Kepemudaan mendefinisikan pemuda yakni mereka yang berumur mulai 16 sampai 30 tahun. Dalam kenggotaan Karang Taruna diatur bahwa mereka yang bisa menjadi anggota yaitu mereka yang berumur 13-45 tahun sedangkan yang bisa menjadi pengurus mulai dari tingkat kelurahan hingga nasional yakni mereka yang berumur 17- 45 tahun (UU Kepemudaan, 2009).

Untuk terciptanya pelaksanakaan komunikasi, konsultasi, informasi, koordinasi, konsolidasi, dan kolaborasi, dibentuk pengurus Karang Taruna mulai dari tingkat tingkat kelurahan/desa, kecamatan, tingkat kabupaten/ kota, provinsi dan yang tertinggi di pusat yakni kepengurusan nasional. Kepengurusan Karang Taruna ini sebagai sarana organisasi yang akan melaksanakan segala tata aturan hingga program kerja melalui kepengurusan di setiap lingkup wilayah masing-masing. Hirarki kepengurusan kepengurusan Karang Taruna meliputi pengurus dan dewan pertimbangan.

Pengurus Karang Taruna mulai dari tingkat kelurahan/desa yang bertanggung jawab 
pada pengurus kecamatan. Begitu seterusnya pengurus kecamatan bertanggungjawab pada pengurus kabupaten, ke pengurus provinsi dan paling tinggi ada pada pengurus nasional. Dewan pertimbangan berkedudukan mulai di tingkat kabupaten/kota, provinsi dan ada di tingkat nasional. Dewan pertimbangan mempunyai tugas sebagai penasehat untuk memberikan masukan dan meminta masukan dari setiap langkah yang akan dilakukan oleh pengurus di tingkatnya masing-masing.

Syarat utama untuk menjadi pengurus Karang Taruna tingkat kabupaten yakni merupakan pengurus dari Karang Taruna tingkat kecamatan atau minimal pernah menjabat pengurus tingkat kecamatan. Dari segi umur mereka yang bisa duduk menjadi pengurus Karang Taruna sudah ditentukan dalam AD/ART mereka yakni para pemuda yang berusia antara 17-x45 tahun, warga negara Indonesia dan berdomisili sesuai dengan kabupaten tempat kedudukannya. Di Karang Taruna Kabupaten Bantul, kepengurusan menggunakan syarat-syarat seperti yang ada dalam AD/ART, dimana mereka yang saat ini menjadi pengurusnya merupakan mantan pengurus Karang Taruna tingkat kecamatan.

Masa kepengurusan satu periode di Karang Taruna, sesuai dengan AD/ARTnya yakni selama 5 tahun. Dalam masa lima tahun tersebut seorang pengurus Karang Taruna bisa dipilih dan diajukan menjadi pengurus Karang Taruna di tingkat yang lebih tinggi. Aturan lainnya tidak menyebutkan berapa kali seseorang bisa dipilih kembali menjadi pengurus Karang Taruna. Kepengurusan Karang Taruna dipilih melalui pemilihan setiap lima tahun sekali. Selanjutnya mereka yang dipilih dilantik oleh pengurus Karang Taruna yang kedudukanya lebih tinggi dari pengurus yang dilantik. Karang Taruna Kabupaten Bantul telah menjalani tahapan sebagaimana yang disyaratkan dalam AD/ ART pada tahun 2014 silam.

Pengurus Karang Taruna Kabupaten Bantul periode tahun 2014 - 2018 telah terpilih dan disyahkan melalui Temu Karya Daerah Karang Taruna Kabupaten Bantul pada tanggal 24 April 2014. Pengurus periode 2014-2018 ini dilantik oleh Karang Taruna DI Yogyakarta, yang dipimpin oleh ketuanya dalam pengambilan sumpah pengurusnya. Kepengurusan Karang Taruna Kabupaten Bantul periode kali ini merupakan hasil pemilihan di masa transisi politik pada masa Pemilu 2014. Kepengurusan Karang Taruna Kabupaten Bantul ini merupakan representasi dari 17 kecamatan se- Kabupaten Bantul karena ruang lingkup kerja Karang Taruna Kabupaten Bantul adalah mengkoordinasi 17 kecamatan dan 75 desa se-kabupaten.

Kepengurusan lain yang melekat pada Kepengurusan Karang Taruna Tingkat Kabupaten yakni Majelis Pertimbangan Karang Taruna. Majelis Pertimbangan Karang Taruna disingkat MPKT merupakan wadah penghimpun mantan pengurus Karang Taruna dan tokoh masyarakat lain yang berjasa dan bermanfaat bagi kemajuan Karang Taruna, yang tidak memiliki hubungan struktural dengan kepengurusan Karang Taruna-nya. Setiap Karang Taruna dapat membentuk MPKT yang dilakukan melalui Forum Temu Karya di masing-masing wilayahnya, yang kemudian dikukuhkan oleh forum tersebut. Susunan MPKT terdiri dari seorang ketua merangkap anggota, seorang sekretaris merangkap anggota, beberapa wakil sekretaris (sesuai kebutuhan) merangkap anggota, dan anggota yang jumlahnya ditentukan 
sesuai dengan jumlah mantan aktivis Karang Taruna di wilayah masing-masing ditambah beberapa tokoh yang dianggap layak apabila memungkinkan.

Fungsi dari MPKT yakni memberikan masukan berupa pemikiran-pemikiran atau saran-saran dan bantuan, sebagai bahan pertimbangan Pengurus Karang Taruna dalam menyelenggarakan program kegiatan. MPKT dapat diikutsertakan dalam rapat atau pertemuan yang diselenggarakan Pengurus Karang Taruna. MPKT ini juga merupakan semacam badan pertimbangan setiap kali Karang Taruna akan membuat keputusan. Selain itu MPKT juga bisa mengusulkan sesuatu kepada pengurus Karang Taruna.

\section{Persepsi Pemuda Tentang Keistimewaan Yogyakarta}

Persepsi tentang keistimewaan Yogyakarta para pemuda Kabupaten Bantul khususnya mereka yang menjadi pengurus Karang Taruna tingkat Kabupaten Bantul pada prinsipnya sama, yakni mendukung keistimewaan itu. Hal ini dapat dilihat dari hasil FGD yang dilakukan pada Minggu 11 Januari 2015. Dari hasil FGD tersebut diketahui bahwa hampir seluruh pengurus Karang Taruna Bantul mengetahui tentang keistimewaan Yogyakarta.

Selain pengurus yang mengikuti FGD ada beberapa pengurus Karang Taruna Bantul yang turut diwawacarai. Dari beberapa orang yang diwawancarai tersebut menyebutkan bahwa mereka sebagai pemuda dan juga pengurus anggota Karang Taruna mengetahui tentang keistimewaan DIY. Pengetahuan mereka tentang keistimewaan minimal tentang apa yang istimewa di DIY, dasar hukum dan sedikit sejarah tentang awal status keistimewaan Yogyakarta.
Selain persepsi tentang keistimewaan Yogyakarta, para pemuda terutama pengurus Karang Taruna Kabupaten Bantul, juga peneliti minta untuk mengutarakan pendapatnya terkait dengan kewenangan kelembagaan, kepemimpinan Yogyakarta, kewenangan kebudayaan, kewenangan pertahanan, kewenangan tata ruang, dan tentang suksesi kepemimpinan Daerah Istimewa Yogyakarta pasca Sri Sultan HB IX.

Pertama, dari hasil FGD dan wawancara dengan pengurus Karang Taruna Kabupaten Bantul terkait dengan kewenangan kelembagaan diketahui bahwa para pemuda terutama mereka yang tergabung dalam kepengurusan Karang Taruna Kabupaten Bantul secara bulat mendukung kewenangan kelembagaan yang dibentuk oleh pemerintah dan yang termuat dalam UU Nomor 13 Tahun 2012 Tentang Keistimewaan Daerah Istimewa Yogyakarta, dan juga yang termuat dalam Perdais Induk No 1 Tahun 2013. Dukungan Karang Taruna Bantul atas kewenangan kelembagaan itu diimplementasikan dengan cara turut menyosialisasikan lembaga-lembaga yang sudah dibuat oleh pemerintah daerah.

Kedua, mengenai kepemimpinan Yogyakarta, para pemuda khususnya mereka pengurus Karang Taruna Kabupaten Bantul mempunyai pandangan tersendiri. Hal ini terungkap dalam sesi wawancara maupun Fokus Group Diskusi (FGD) yang dilakukan dalam penelitian ini. Menurut mereka kepemimpinan di Yogyakarta adalah tunggal, dalam artian baik pemimpin politik atau struktural maupun pimpinan kultural adalah satu.

Menurut para pengurus Karang Taruna Kabupaten Bantul, pengangkatan atau penunjukan Sultan dan Paku Alam otomatis 
sebagai gubernur dan wakilnya merupakan keistimewaan yang melekat secara historis dan konstitusional Pengangkatan gubernur dan wakilnya tidak bertentangan dengan hukum nasional karena mempunyai payung hukum sebagai landasan konstitusinya.

Ketiga, terkait dengan kewenangan kebudayaan, para pemuda yang masuk dalam kepengurusan Karang Taruna Kabupaten Bantul periode 2014-2018 yang sedang menjabat saat ini, belum banyak yang mengetahui karena minimnya sosialisasi yang dilakukan pemerintah. Hal ini diketahui dari hasil FGD dan juga wawancara, yang umumnya budaya menurut para pemuda lebih banyak sebatas tentang seni tradisi budaya dan juga benda serta situs cagar budaya.

Keempat, masyarakat khususnya pemuda yang menjadi pengurus Karang Taruna Kabupaten Bantul memiliki persepsi tersendiri terhadap kewenangan istimewa dalam hal pertanahan. Banyak masyarakat yang tidak utuh dalam memahami kewenangan pertanahan yang dimiliki oleh keraton dan paku alam. Termasuk juga para pemuda yang menjadi pengurus Karang Taruna Bantul. Menurut beberapa orang yang diwawancarai dalam penelitian ini mereka memandang bahwa kewenangan istimewa ini merupakan hak keraton dan paku alam yang mempunyai hak atas tanah sejak zaman dahulu. Pendapat lain mengatakan bahwa hak istimewa atas pengelolaan tanah di wilayah DIY merupakan kewenangan melekat karena Keraton Ngayogyakarta Hadiningrat dan Paku Alaman sudah ada sejak jauh hari sebelum Negara Indonesia berdiri.

Kelima, menanggapi tentang tata ruang dan hak istimewa yang melekat pada pemerintah dalam pengaturan tata ruang terjadi perbedaan persepsi di antara pengurus Karang Taruna Kabupaten Bantul. Perbedaan persepsi ini bukan soal setuju atau tidak namun lebih pada soal siapa yang lebih berhak mengelola tata ruang ini. Setelah melalui perdebatan panjang akhirnya bisa ditarik kesimpulan bahwa para pemuda yang menjadi pengurus Karang Taruna Kabupaten Bantul menyadari bahwa perlunya DIY memiliki tata ruang sendiri yang sesuai dengan status keistimewaan. Hal ini karena, menurut mereka tata ruang di Daerah Istimewa Yogyakarta banyak yang sudah menyalahi aturan, mulai dari yang terjadi di Kota Yogyakarta hingga di kabupaten-kabupaten lainya. Salah satu contohnya ialah banyaknya hotel dan pusat perbelanjaan moderen yang saat ini dibangun terindikasi terjadi penyalahgunaan peruntukan lahan.

Keenam, dalam prosesi kepemimpinan Keraton Yogyakarta ini ada beberapa persepsi di kalangan pemuda yang menjadi pengurus di Karang Taruna Kabupaten Bantul periode 2014-2018. Persepsi pertama yakni mereka yang mendukung kepemimpinan perempuan pasca Sri Sultan Hamengku Buwono X yang saat ini bertakhta. Menurut mereka, sejarah raja di Jawa yang selalu laki-laki merupakan bentuk budaya patriaki. Padahal, dalam kedudukannya seharusnya perempuan setara dengan laki-laki. Jenis kelamin tidak bisa menjadi penghalang bagi umat manusia untuk mengaktualisasikan diri termasuk menjadi seorang pemimpin.

Pemimpin hendaknya merupakan orang yang mampu mempunyai kecakapan untuk menjadi panutan. Jika syarat-syarat menjadi pemimpin dimiliki oleh seorang perempuan, maka kesempatan itu juga harus terbuka lebar setara dengan kesempatan yang dimiliki 
seorang laki-laki. Dalam menanggapi tentang raja perempuan sebagian dari pengurus Karang Taruna Kabupaten Bantul khususnya pengurus perempuan berpersepsi bahwa raja perempuan boleh dan itu merupakan bagian dari emansipasi wanita di era modern. Mereka yang setuju dengan raja perempuan juga mempunyai pandangan bahwa budaya patriaki dalam budaya Jawa sudah tidak relevan lagi dengan perkembangan zaman, sehingga budaya-budaya patriaki yang menempatkan perempuan pada manusia kelas dua harus sudah dihapus.

\section{Implikasinya Bagi Ketahanan Politik Wilayah}

Dalam teori perilaku dinyatakan bahwa sikap terhadap suatu perilaku dipengaruhi oleh keyakinan dalam pemikiran termasuk persepsi seseorang bahwa perilaku tersebut akan membawa kepada hasil yang diinginkan atau tidak diinginkan. Dalam hal ini persepsi pemuda tentang keistimewaan Yogyakarta berimplikasi terhadap beberapa apsek, yaitu implikasi terhadap Karang Taruna Bantul, implikasi terhadap kesadaran politik, implikasi bagi legitimasi Pemerintah Daerah Istimewa Yogyakarta dan Keraton Yogyakarta, implikasi terhadap stabilitas politik Daerah Istimewa Yogyakarta, dan implikasi bagi ketahanan wilayah Daerah Istimewa Yogyakarta.

Pertama, implikasi terhadap Karang Taruna Kabupaten Bantul periode 20142018, dapat dilihat pada visi yang mereka tetapkan dalam kepengurusan mereka. Visi kepengurusan Karang Taruna Kabupaten Bantul Periode 2014-2018 yakni 'Dengan Semangat Keistimewaan Bersama-sama Membangun Pemuda Bantul Menjadi Pemuda Yang Nasionalis, Toleran, dan Berwibawa'.
Selain itu, terkait dengan keistimewaan Yogyakarta, dalam wawancara terpisah ketua Karang Taruna Kabupaten Bantul, M. Sholinurudin mengatakan bahwa dirinya dan juga Karang Taruna Kabupaten Bantul sepenuhnya mendukung keistimewaan Yogyakarta. Lebih jauh lagi M. Sholinurudin mengatakan bukti nyata dari dukungan tersebut bisa dilihat dari misi kepengurusan Karang Taruna Bantul Periode 2014-2018. Dalam poin pertama yakni mewujudkan Keistimewaan DIY melalui segala bidang. Hal tersebut mengindikasikan bahwa poin pertama dari visi ini merupakan implikasi pengaruh persepsi pemuda Karang Taruna terhadap status keistimewaan Yogyakarta.

Kedua, implikasi terhadap kesadaran partisipasi politik, dalam hal ini Karang Taruna sebagai organisasi yang didirikan oleh pemerintah tidak untuk tujuan sebagai organisasi afiliasi politik tertentu. Sebagai sebuah organisasi, Karang Taruna independen dalam praktek politik, tetapi dalam prakteknya para anggota dan pengurusnya sebagian besar memiliki afiliasi politik dengan partaipartai pilihan mereka secara pribadi. Di pemilihan umum tahun 2014 baik pilihan legislatif maupun pilihan presiden, anggota pengurus Karang Taruna Kabupaten Bantul ikut terlibat aktif di dalamnya. Bahkan secara institusi Karang Taruna juga ikut berpartisipasi dalam perhelatan demokrasi lima tahunan tersebut. Secara institusi pada pemilu 2014 silam Karang Taruna ikut membuat beberapa kegiatan sebagai bentuk partisipasinya dalam mendukung dan mensukseskan pemilu.

Partisipasi politik organisasi Karang Taruna ini, merupakan implikasi dari persepsi politik para pengurusnya, yang mempunyai persepsi bahwa politik merupakan jalan 
demokrasi untuk menuju sebuah keadaan yang lebih baik maka dengan bagitu mereka mendukung proses-proses politik tersebut. Persepsi lain yang mempengaruhi partisipasi politik pengurus Karang Taruna salah satunya yakni persepsi mereka terhadap keistimewaan Yogyakarta. Stastus keistimewaan yang disandang oleh Daerah Istimewa Yogyakarta merupakan status politik yang berasal atau diberikan oleh pusat dengan proses politik yang panjang dan sulit. Untuk penetapan status keistimewaan ini, rakyat Yogyakarta harus berjuang secara politik agar dikabulkan oleh pemerintah pusat. Berbagai kegiatan politik mulai dari demonstrasi hingga mendesak anggota DPR dilakukan agar UU keistimewaan yang saat itu mandek pembahasanya kembali dibahas dan diketok palu. Karang Taruna Bantul sebagai institusi sejak memperjuangkan UU keistimewaan sudah berpartisipasi secara langsung. Partisipasi institusi ini dari mengadakan kegiatan diskusi bertajuk keistimewaan hingga ikut memobilisasi massa berdemonstrasi mendukung keistimewaan dan untuk mendesak segera ditetapkan UU untuk hal tersebut.

Ketiga, implikasi bagi legitimasi pemerintahan di Daerah Istimewa Yogyakarta dan Keraton Yogyakarta. Dalam hal ini para pemuda yang tergabung dalam kepengurusan Karang Taruna Kabupaten Bantul periode 2014-2018 memberi apresiasi dan percaya penuh pada pemerintahan yang ada pada saat ini, khususnya pada pemerintah Provinsi DI Yogyakarta yang dalam undang-undangnya merupakan bagian dari kewenangan istimewa yang diberikan pemerintah pusat. Pemerintah Provinsi DI Yogyakarta dipimpin gubernur yang ditetapkan, tidak dipilih oleh rakyat. Dalam hal ini gubernur yaitu SultanYogyakarta dan wakil gubernur adalah Adipati Paku Alam. Dengan ketetapan tersebut, karena persepsi pemuda yang mendukung kedua kepemimpinan tersebut, membuat kepercayaan publik pada pemerintah provinsi sangat tinggi sehingga legitimasinyapun ikut tinggi.

Legitimasi penuh selain diberikan pada pemerintah Provinsi DI Yogyakarta, rakyat juga memberikan dukungan pada penuh pada Keraton Yogyakarta. Legitimasi pada Keraton Yogyakarta sejatinya sudah lahir dan ada jauh hari sebelum polemik keistimewaan Yogyakarta ini bergulir di media massa. Keraton Yogyakarta sejak berdirinya telah mendapat leitimasi penuh dari rakyat Mataram. Hal ini tak lepas dari filosofi Jawa yang menempatkan Sultan sebagai legitimasi Tuhan di muka bumi,sehingga setiap kebijakannya merupakan sabda pendheta ratu yang harus ditaati oleh rakyat. Pengakuan rakyat atas pemerintahan Daerah Istimewa Yogyakarta dan penetapan Undang-Undang Keistimewaan Yogyakarta oleh pemerintah pusat merupakan bentuk legitimasi kekuasaan yang disandang oleh Daerah Istimewa Yogyakarta dengan tidak mengesampingkan sistem demokrasi yang telah berjalan.

Keempat, implikasi bagi stabilitas politik Daerah Istimewa Yogyakarta. Stabilitas dan dinamika politik di suatu daerah mempengaruhi ketahanan wilayah suatu daerah. Dengan kata lain, indikator ketahanan politik wilayah dapat dilihat dari stabilitas dan dinamika politik di daerah tersebut. Secara umum stabilitas politik di Daerah Istimewa Yogyakarta stabil, dalam arti bahwa tidak ada gejolak-gejolak politik yang berarti di DIY ini. Kondisi politik yang stabil membuat pemerintah selaku pengelola negara bisa berkonsentrasi pada cita-cita untuk mewujudkan kesejahteraan ekonomi 
masyarakat. Sebaliknya, situasi politik yang kacau membuat pemerintah terlebih dahulu harus memprioritaskan terciptanya situasi kondusif sebelum melakukan pembangunan, karena pembangunan yang dilangsungkan di dalam sebuah daerah konflik, seringkali tersendat dan tidak jarang menemui jalan buntu.

Kelima, implikasi bagi ketahanan politik wilayah Daerah Istimewa Yogyakarta. Pasca Sabdaraja 5 Mei 2015 terjadi perbedaan pandangan antara Sri Sultan Hamengku Buwono X dengan adik-adik beliau terkait dengan suksesi kepemimpinan Keraton Yogyakarta. Persepsi masyarakatpun beragam menanggapi suksesi kepemimpinan tersebut, hal tersebut tentunya berimplikasi pada ketahanan politik wilayah di Daerah Istimewa Yogyakarta karena kekuatan politik keraton terletak pada kekuatan budayanya.

Dalam sebuah wawancara salah seorang informan mengatakan bahwa meskipun terjadi perbedaan pandangan terkait dengan suksesi kepemimpinan keraton, hal tersebut merupakan dinamika politik di Daerah Istimewa Yogyakarta dan merupakan bagian dari essensi keistimewaan Yogyakarta itu sendiri yang berlandaskan dan berasaskan prinsip -prinsip demokrasi dalam pelaksanaan Undang Undang keistimewaan Yogyakarta.

Meskipun terjadi perbedaan pendapat di Keraton Yogyakarta sampai saat ini belum ada kejadian-kejadian yang melibatkan massa yang besar dan provokasi-provokasi yang berindikasi melanggar hukum negara. Perbedaan pendapat dimunculkan melalui media massa. Aktifitas pelayanan publik pemerintah Daerah Istimewa Yogyakarta juga masih berjalan dengan lancar seperti biasa. Sebagian besar pengurus Karang Taruna
Kabupaten Bantul percaya dan yakin bahwa masalah yang terjadi di Keraton Yogyakarta akan segera selesai dan tidak berdampak luas dalam kehidupan masyarakat Yogyakarta.

\section{SIMPULAN}

Berdasar uraian tersebut dapat ditarik simpulan sebagai berikut:

Pertama, Karang Taruna Kabupaten Bantul merupakan organisasi kepemudaan berkedudukan di kabupaten berada di bawah koordinasi Karang Taruna Provinsi DI Yogyakarta dan berada dua tingkat dari pengurus Karang Taruna Tingkat Nasional. Karang Taruna Kabupaten Bantul membawahi Karang Taruna tingkat kecamatan dan kelurahan. Kepengurusan Karang Taruna Kabupaten Bantul periode 2014-2018 memiliki visi “Dengan Semangat Keistimewaan Bersama-sama Membangun Pemuda Bantul Menjadi Pemuda Yang Nasionalis, Toleran, dan Berwibawa”.

Kedua, pemuda di Kabupaten Bantul khususnya mereka yang menjadi anggota sekaligus pengurus Karang Taruna Tingkat Kabupaten Bantul mendukung sepenuhnya status keistimewaan Yogyakarta yang telah ditetapkan melalui UU No. 13 Tahun 2012 oleh pemerintah pusat. Mereka, pengurus Karang Taruna Bantul ini juga mengerti betul apa makna dari status keistimewaan. Persepsi mereka tentang keistimewaan Yogyakarta yakni hak istimewa yang diberikan oleh undang-undang dalam mengatur beberapa kebijakan.

Ketiga, persepsi pemuda tentang keistimewaan Yogyakarta berimplikasi kepada ketahanan politik wilayah. Meskipun tidak ada proses pemilihan dalam penetapan gubernur dan wakil gubernur Daerah Istimewa 
Muhammad Pranasik Faihaan -- Persepsi Pemuda Tentang Keistimewaan Yogyakarta Bagi Ketahanan Politik Wilayah (Studi Pada Pengurus Karang Taruna Kabupaten Bantul Periode 2014-2019)

Yogyakarta, situasi politik di Daerah Istimewa Yogyakarta tetap relatif tangguh dengan adanya legitimasi dari rakyat Yogyakarta yang masih sangat tinggi kepada Sri Sultan hamengku Buwono X dan Sri Paduka Paku Alam XIII dan legitimasi pemerintah pusat melalui UU No 13 Tahun 2012 tentang Keistimewaan Yogyakarta.

Selanjutnya, berdasar kesimpulan tersebut disarankan hal-hal sebagai berikut:

Pertama, meningkatan kapasitas sumber daya manusia pengurus Karang Taruna Kabupaten Bantul dengan melakukan berbagai kegiatan.

Kedua, Pemerintah Kabupaten Bantul harus lebih memperhatikan pemuda di daerahnya dengan melibatkan para pemuda ini dalam berbagai kegiatan dan penentuan kebijakan pemerintah.

Ketiga, Pemerintah Daerah Istimewa Yogyakarta semestinya mensosialisasikan status keistimewaan Daerah Istimewa Yogyakarta kepada masyarakat luas khususnya pemuda di Kabupaten Bantul.

Keempat, melibatkan masyarakat khususnya pemuda di Kabupaten Bantul dalam berbagai kebijakan dan kegiatan yang berkaitan dengan keistimewaan.

Kelima, Keraton Ngayogyakarta Hadiningrat dan Pakualanan harus lebih merangkul kawula muda untuk menjadi bagian dari keistimewaan yang melekat pada institusi kebudayaan ini.

Keenam, Pemerintah Daerah Istimewa Yogyakarta harus meningkatkan berbagai penelitian akademis tentang keistimewaan Yogyakarta untuk menunjang programprogram keistimewaan serta menjaga nilainilai keistimewaan.

\section{DAFTAR PUSTAKA}

Atmakusuma. 1982. Tahtah Untuk Rakyat: Celah-Celah Kehidupan Sri Sultan Hamengkubuwono IX, Jakarta: Gramedia.

Bahar, Saafroedin, 1933. Risalah Sidang BPUPKI-PPKI 29 Mei 1945-19 Agustus 1945. Jakarta: Sekretariat Negara RI.

Arikunto, Suharsimi. 2002. Metodologi Penelitian. Jakarta: PT. Rineka Cipta.

Lemhannas, 1989.Tolak Ukur Kondisi Ketahanan Nasional, Jakarta:PT Balai Pustaka. 1997, Ketahanan Nasional, Jakarta: PT Balai Pustaka.

Rakhmat, Jalaludin. Psikologi Komunikasi. Bandung: PT. Rosda.

\section{Undang-Undang dan Peraturan:}

UU Nomor 3 Tahun 1950 Tentang Pembentukan Daerah Istimewa Yogyakarta.

UU Nomor 40 Tahun 2009 Tentang Kepemudaan.

UU Nomor 13 Tahun 2012 Tentang Keistimewaan Daerah Istimewa Yogyakarta.

UU Nomor 1 Tahun 2015 Tentang Pemilihan Kepala Daerah.

Peraturan Menteri Sosial Nomor 77/ HUK/ 2010 Tentang Pedoman Dasar Karang Taruna

Perdais Nomor 1 Tahun 2013 Tentang Kewenangan Dalam Urusan Keistimewaan Daerah Istimewa Jogjakarta.

\section{Wawancara:}

M. Sholinurudin: Ketua Karang Taruna Kabupaten Bantul 